Basin Research

March 2004; 16(1) : 101-116

http://dx.doi.org/10.1111/j.1365-2117.2003.00224.x

(c) 2004 Blackwell Publishing, Inc.
Archimer, archive institutionnelle de l'Ifremer http://www.ifremer.fr/docelec/

The definitive version is available at www.blackwell-synergy.com

\title{
Polygonal faults-furrows system related to early stages of compaction - upper Miocene to recent sediments of the Lower Congo Basin
}

\author{
A. Gay ${ }^{1 *}$, M. Lopez ${ }^{2}$, P. Cochonat ${ }^{3}$ and G. Sermondadaz ${ }^{4}$ \\ ${ }^{1}$ Laboratoire Sédimentologie et Géodynamique, Université de Lille I, FRE 2255, Bât SN5, 59655 \\ Villeneuve d'Ascq, France \\ ${ }^{2}$ Laboratoire Géophysique Tectonique et Sédimentologie, Université de Montpellier II, CC60, Bât 22, \\ place E. Bataillon, 34095 Montpellier cedex, France \\ ${ }^{3}$ Laboratoire Environnements Sédimentaires, IFREMER, Département Géosciences Marines, BP70, \\ 29280 Plouzané, France \\ ${ }^{4}$ Total-Fina-Elf, 64018 Pau Cedex, France \\ *: Corresponding author : Correspondence: Aurélien Gay, Laboratoire Dynamique de la Lithosphère, Université \\ Montpellier 2, Case 060, Place Eugène Bataillon, 34095 Montpellier Cedex 05, France. \\ E-mail: gay@dstu.univ-montp2.fr
}

\begin{abstract}
A new polygonal fault system has been identified in the Lower Congo Basin. This highly faulted interval $(\mathrm{HFI}), 700 \pm 50 \mathrm{~m}$ thick, is characterized by small extensional faults displaying a polygonal pattern in plan view. This kind of fracturing is attributed to volumetric contraction of sediments during early stages of compaction at shallow burial depth. 3-D seismic data permitted the visualization of the progressive deformation of furrows during burial, leading to real fractures, visible on seismic sections at about $78 \mathrm{~m}$ below seafloor. We propose a new geometrical model for volumetrical contraction of mud-dominated sediments. Compaction starts at the water-sediment interface by horizontal contraction, creating furrows perpendicular to the present day slope. During burial, continued shrinkage evolves to radial contraction, generating hexagonal cells of dewatering at $21 \mathrm{~m}$ below seafloor. With increasing contraction, several faults generations are progressively initiated from 78 to $700 \mathrm{~m}$ burial depth. Numerous faults of the HFI act as highly permeable pathways for deeper fluids. We point out that pockmarks, which represent the imprint of gas, oil or pore water escape on the seafloor, are consistently located at the triple-junction of three neighbouring hexagonal cells. This is highly relevant for predictive models of the occurrence of seepage structures on the seafloor and for the sealing capacity of sedimentary cover over deeper petroleum reservoirs.
\end{abstract}

Keywords: Fault system, Furrow, Geometrical model, Sedimentary basin, Seafloor, Water sediment interface 


\section{INTRODUCTION}

Over large areas of the Lower Congo Basin, mud-dominated upper Miocene to lower Quaternary sequences, $700 \mathrm{~m}( \pm 50 \mathrm{~m})$ thick, are affected by closely spaced small extensional faults displaying a polygonal pattern in plan view. Within this Highly-Faulted Interval (HFI), the polygonal fault system consists of small-scale normal faults with throws from 5 to $20 \mathrm{~m}$ and small spacing of 100 to $500 \mathrm{~m}$. As previously shown in the North Sea, the presence of polygonal fault systems seems to be controlled by the fine-grained nature of the faulted sediments and their mineralogy; in particular a high smectite content is considered to play an important role in the development of such structures (Dewhurst et al., 1999). The faults are often arranged in stratigraphycally bound layers characterized by a distinct spacing between faults (Lonergan et al., 1998), which could be due to different lithologies within the layers (Dewhurst et al., 1999).

The first mechanism suggested for polygonal faulting formation was that the highly overpressured sediments of the slope and basin failed through a basinwide hydrofracture mechanism (Henriet et al., 1991; Cartwright, 1994a,b). This hypothesis has subsequently been revised and the faulted intervals are now interpreted as being caused by layer-parallel volumetric contraction of fine-grained sediments leading to pore fluid escape (Cartwright \& Lonergan, 1996). This kind of shrinkage is also known in other environments, such as cooling of lavas, ice-wedge polygons (Lachenbruch, 1962) or desiccation cracks (Weinberger, 1999). Cartwright \& Dewhurst (1998) conducted a worldwide review of published and unpublished seismic data from approximately 200 basins, in order to determine whether this type of small-scale faulting is more widely developed than currently appreciated. They identified several examples of such faulting in the North Sea (Cartwright, 1994a,b; Lonergan et al., 1998; Clausen et al., 1999), in the northern Danish Central Trough (Clausen \& Korstgard, 1993) in the Eromanga Basin (Cartwright \& Lonergan, 1997; Oldham \& Gibbins, 1995), on the New Jersey continental margin (Klitgord \& Grow, 1980; Poag et al., 1987). They also discussed the presence of polygonal fault systems in the northern Bay of Biscay, in the Rockall Trough in Ireland, or in the Vøring Basin on the Norwegian continental margin. All of these basins are characterized by a similar sedimentary environment suggesting that the polygonal fault systems could have formed through equivalent processes.

We propose in this paper a geometrical model of differential dewatering during early stages of compaction, related to heterogeneous compaction in the first $700 \mathrm{~m}$ below seafloor. A detailed study of the organisation of faults and furrows shows that the pockmarks are consistently located at the intersection of three neighbouring hexagons, representing a preferential pathway for upwards-fluid migration from deeper levels (biogenic gases, thermogenic gases and oils, pore fluids or a combination of the three). This could be indicative of deeper prospective reservoirs and improve our knowledge of the sealing capacity of sedimentary cover over the reservoirs. 


\section{A. Gay et al}

\section{GEOLOGICAL SETTING}

The West African passive margin was initiated during the opening of the South Atlantic Ocean in the Early Cretaceous (130 Ma) (Jansen et al., 1984; Marton et al., 2000). Subsequent to large accumulation of evaporites (up to $1000 \mathrm{~m}$ ) during midAptian time, the post-rift stratigraphy was characterized by two architectures that reflect a major change in ocean circulation and climate. From the Late Cretaceous to the early Oligocene, an aggradational carbonate/siliciclastic ramp developed in response to low-amplitude/low-frequency sea-level changes and a uniform climate (greenhouse period). From early Oligocene to Recent, sedimentation was dominated by the progradation of a terrigenous wedge that reflect high-amplitude/high-frequency sea-level changes and an alternating drier and wetter climate (Icehouse period) leading to subaerial exposure of wide parts of the ramp on the West African margin (Séranne et al., 1992; Séranne, 1999; Lavier et al., 2000; 2001). These highfrequency alternating climate conditions triggered deep incision on the shelf and erosion of the hinterland, and large amounts of terrigenous material were supplied to the margin leading to the formation of a 2-3 km-thick progradational wedge. In particular, the increased terrigenous input to the margin was responsible for the formation of the large turbiditic fan off the Congo and Angola slope directly fed by the Zaire River (Brice et al., 1982; Uchupi, 1992; Droz et al., 1996). It extends from the Zaire River estuary to the lower fan, $5000 \mathrm{~m}$ water depth (Fig. 1). The shelf and the slope are deeply incised by a canyon that directly connects the Zaire River with the basin floor at the toe of the continental slope. The Zaire canyon crosses the Lower Congo Basin (Fig. 1) and is characterized by a straight erosional trough (Droz et al., 1996). Recent drilling carried out in ODP Leg 175 has supplied new information about the nature and age of these sediments. Three sites were drilled at varying positions from the shelf break (sites 1075, 1076 and 1077) within the Lower Congo Basin (see Fig. 1 for location). The lithofacies of the Late Cenozoic sediments suggests that turbidity currents played a minimal role in transporting sediment within the Lower Congo Basin (Giraudeau et al., 1998; Pufahl et al., 1998). Sediments fed through the canyon were carried far onto the lower fan, starving the shelf of coarse detritus (Jansen et al., 1984; Uenzelmann-Neben, 1998; Savoye et al., 2000). On the slope and shelf, fine sediments not confined to the canyon were deposited, perhaps from riverine plumes, through sedimentation by aggregates and in fecal pellets (Wefer et al., 1998; Cooper, 1999) and mixed with hemipelagic sediments. 
Figure 1: Bathymetric map of the Zaire turbidite system, extending from the Zaire estuary to the deep sea fan. The shaded circle represents the study area in the Lower Congo Basin. The three sites of the Leg ODP175 in this zone are indicated.

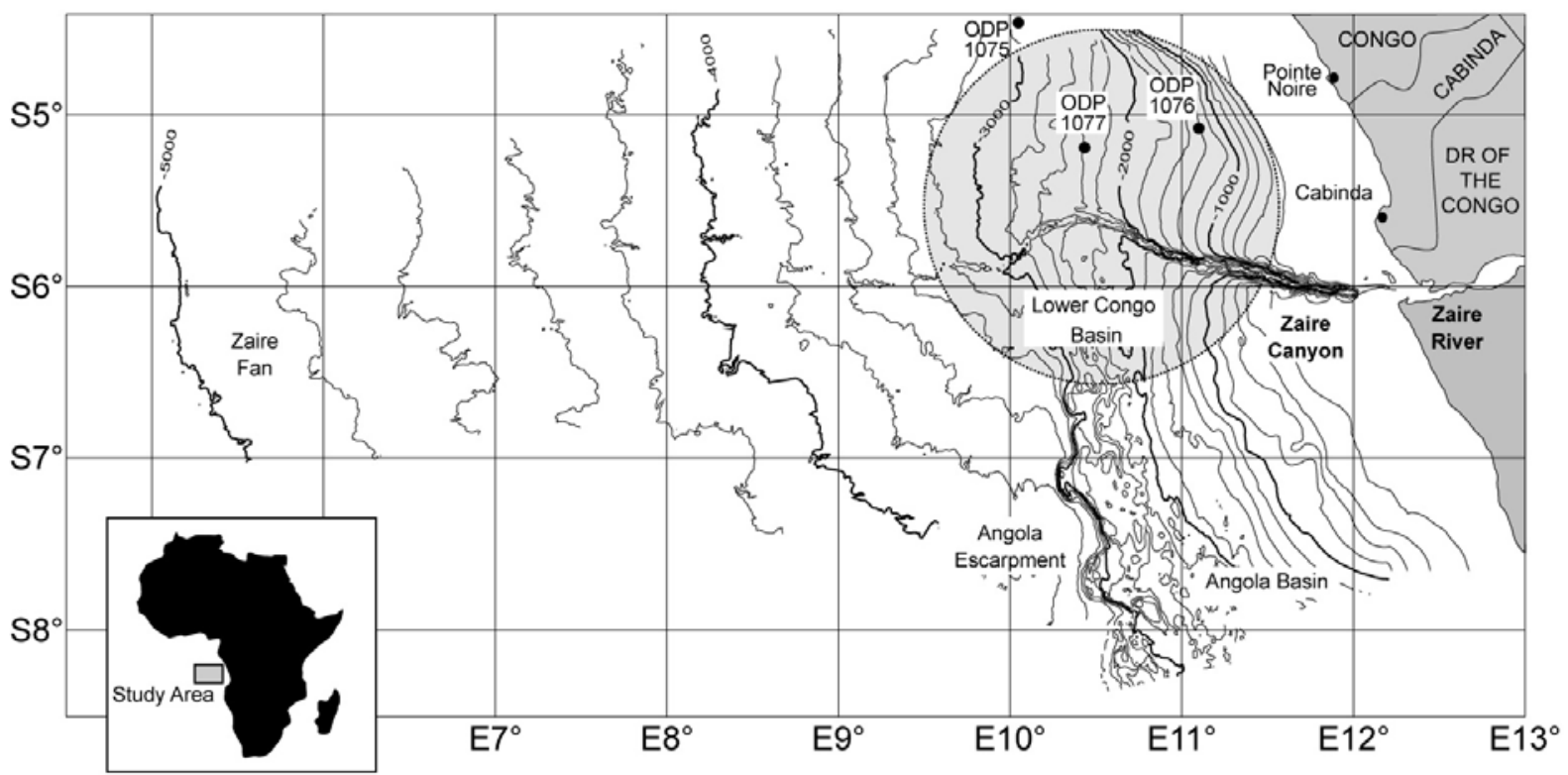

One of the main tectonic features of the West African margin is the gravitational sliding of post-rift sediments above a décollement layer made up of Aptian evaporites (Duval et al., 1992; Lundin, 1992; Liro \& Coen, 1995). In the Lower Congo Basin, gravitational processes created two structural domains each about 100 $\mathrm{km}$ wide: an extensional domain on the upper slope and a compressive domain located downslope (Fig. 2). The extensional domain is locally associated with large amounts of extension across listric faults creating individual rafts (Burollet, 1975; Duval et al., 1992; Rouby et al., 2002). The compressive domain is characterized by reverse faults leading to the intrusion of salt diapirs that partly control turbidite distribution and basin sedimentation. 


\section{A. Gay et al}

Figure 2: Seafloor Dip map, representing the area covered by 3D seismic data used in this study. In the southwestern part, the salt thrust intensively deforms the seafloor. In the central part of the study area, the Zaire canyon, oriented SE-NW currently incises the slope of the Lower Congo Basin. The seafloor is characterized by numerous rectilinear depressions, named furrows, that are mainly oriented NS and a large number of pockmarks seems to be in close association with these furrows. All seismic profiles and detailed study area used in this study are located on this map.

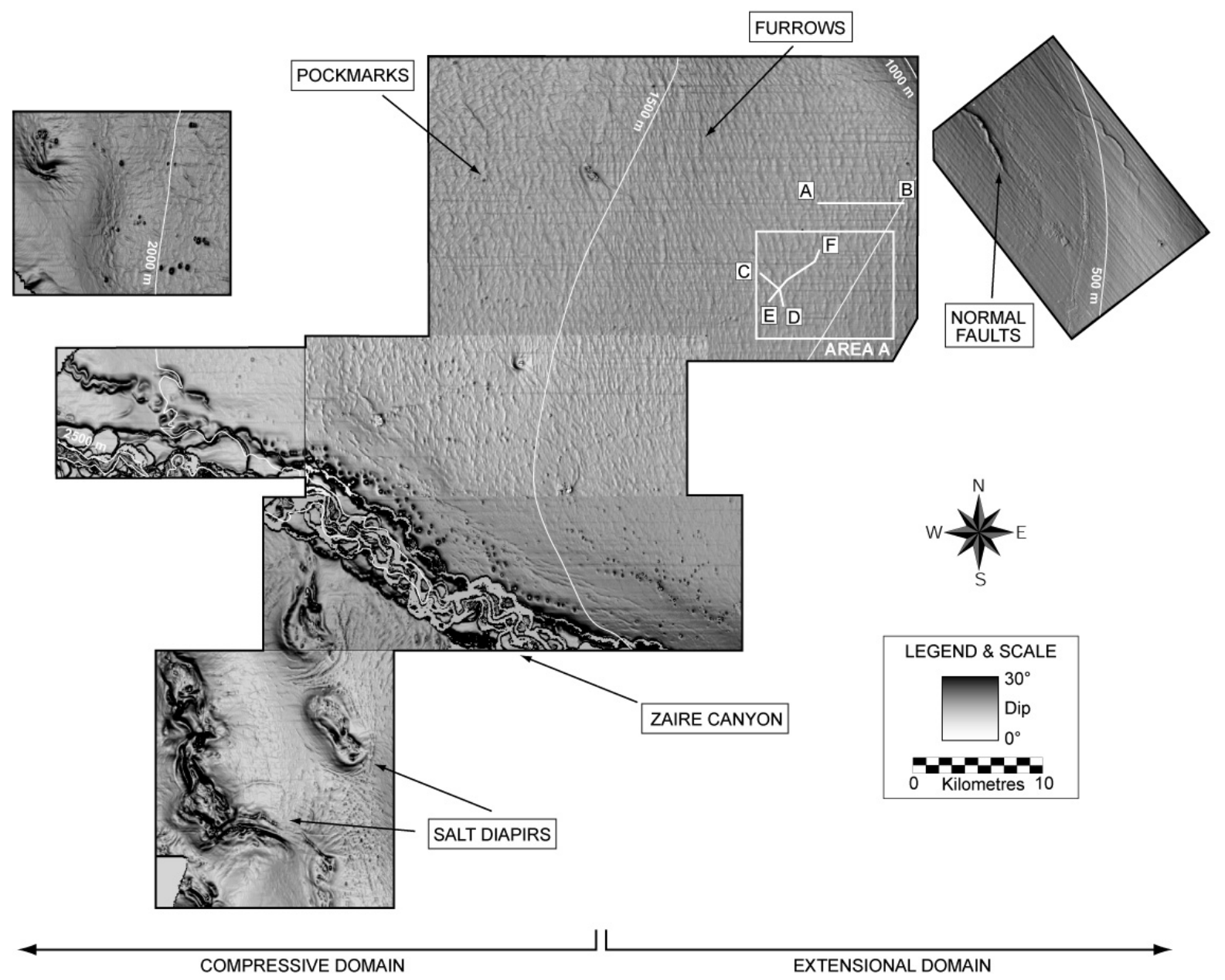

\section{DATA BASE AND PROCESSING}

This study was primarily based on 3D seismic datasets from the Lower Congo Basin acquired by TotalFinaElf. Complementary data have been collected during the ZAIANGO project (co-sponsored by IFREMER and TotalFinaElf) and partly focused on a better understanding of the Quaternary Zaire fan and slope processes. Further data from ODP leg 175 on the West African Margin helped to constrain stratigraphy, sedimentation rates and mechanical properties of Pliocene to Recent sediments (Wefer et al., 1998).

The selected 3D-dataset covers an area of $4150 \mathrm{~km}^{2}$ with inline and crossline spacing of $12,5 \mathrm{~m}$ (Fig. 2). 3D-seismic analysis consists in extraction of continuous horizons by correlation through the 3D seismic block (Brown, 1996; Kidd, 1999). This process correlates the shape of the wavelength from each trace to the neighbours within a time interval determined by the interpreter. Other horizon attributes, derived 
from the seismic signal, have been calculated. In particular, we mainly used geometrical attributes such as the Dip attribute and the Curvature attribute (Brown, 1996).

\section{FABRIC OF THE HIGHLY-FAULTED INTERVAL (HFI)}

The seismic section $A B$ (Fig. 3) is representative of some seismic key features of the Highly-Faulted Interval (HFI) in the investigated area. It is characterized by numerous closely spaced normal faults, which have small offsets, ranging from 5 (limit of vertical resolution) to $20 \mathrm{~m}$, and an average spacing of 100$500 \mathrm{~m}$. This pattern has been identified throughout the study area, at water depths ranging from $400 \mathrm{~m}$ to $2600 \mathrm{~m}$ (dataset limits), indicating that the occurrence of this interval is not controlled by the bathymetry. The faults of the HFI disappear downward close to the base of the Pliocene and upward towards the base of the Quaternary, affecting an interval with an average thickness of $700 \mathrm{~m}( \pm 50 \mathrm{~m})$. As previously shown in the North Sea (Cartwright, 1994a,b), the faults do not abruptly end at a specific horizon. Some faults can locally offset the base of the Quaternary and the base of the Pliocene, suggesting that the vertical extent of the HFI is not stratigraphically bounded. Vertically, the discontinuous reflection character of the faulted system is not homogeneous. The HFI is ordered into individual layers of faults, named tiers by Cartwright (1994b), characterized by a distinct fault spacing and vertical extent (Fig. 3). In the North Sea, Dewhurst et al. (1999) have shown that the maximum fault frequency occurs in layers that include high amplitude reflectors corresponding to very fine-grained sediments. However, this high concentration of faults at highly reflective interval may be a bias caused by the increased detectability at such intervals. It thus appears that, although the vertical extent of the HFI is not stratigraphically controlled in the Lower Congo Basin, lithology could play a key role in the development and in the inhomogeneous frequency of faults. 
Figure 3: Seismic profile $A B$ in the Lower Congo Basin. The upper Miocene to lower Quaternary interval is affected by closely spaced extensional faults, displaying a polygonal pattern in plan view. This Highly-Faulted Interval (HFI) consists of small scale normal faults with offsets from $5 \mathrm{~m}$ to $30 \mathrm{~m}$ and small spacing of 100 to $500 \mathrm{~m}$. The polygonal fault system is organized in stratigraphically defined layers, with the deformation apparently being decoupled between the layers. Each layer of faults is characterized by a distinct acoustic character.

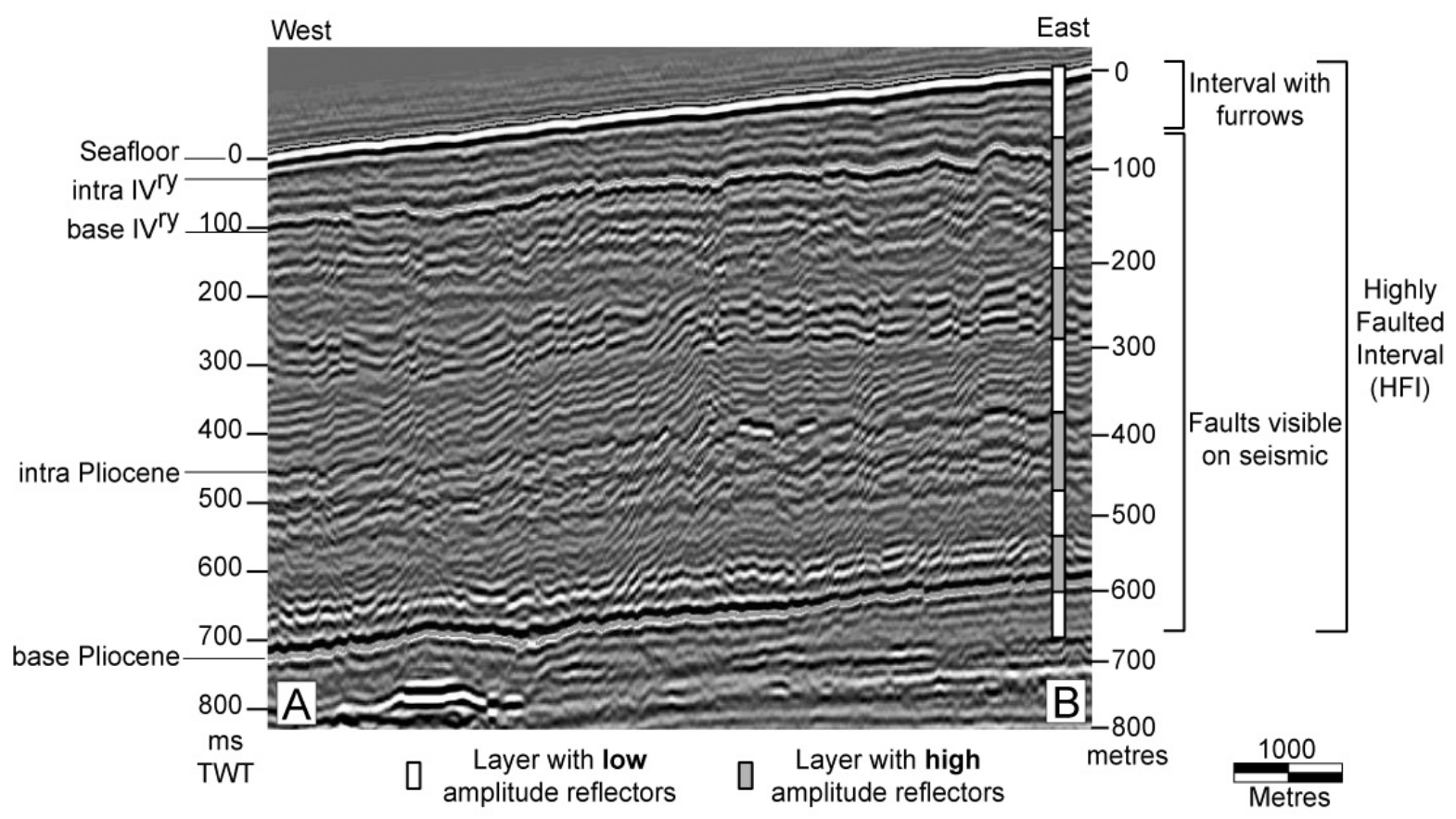

In the northern part of the study area, a large number of rectilinear depressions a few hundred metres long are visible on a dip map of seafloor (Fig. 4). These furrows are widely distributed on the seafloor (Fig. 4A) with a N-S trend and a spacing of about 1 to $3 \mathrm{~km}$. In the same area, a dip map of a horizon about $20 \mathrm{~m}$ below seafloor (Fig. 4B) displays parallel furrows in the West evolving to a polygonal network in the East. The later observation confirms the spatial close relationship between the furrows and the polygonal faulting. The base of the Quaternary (Fig. 4C) corresponds to a regionally well-defined high amplitude reflector that can be easily mapped by automatic correlation. The dip map of this horizon also displays a dense polygonal fault pattern at the difference with the base of Pliocene (Fig. 4D), where only regional tectonic and sedimentological structures are visible: 1) normal faults oriented NW-SE bounding a graben in the northeastern part of the study area; 2) reverse faults in the central and in the western part, related to the intrusion of salt diapirs; 3) the imprint of underlying (i.e. upper Miocene) turbiditic channels. 


\section{A. Gay et al}

Figure 4: Dip maps of seafloor, a intra-Quaternary horizon, the base Quaternary and the base Pliocene. The seafloor is characterized by numerous furrows that are mainly N-S oriented. The dip map of intra Quaternary displays furrow organization 1) similar to the seafloor in the western part and 2) forming a polygonal pattern in the eastern part. We have measured the length and the azimuth of all furrows located within the black frame (Area A) on the seafloor and on the intra Quaternary horizon. The dip map of the base Quaternary displays polygonal faults. The base Pliocene may be not affected by the polygonal pattern.

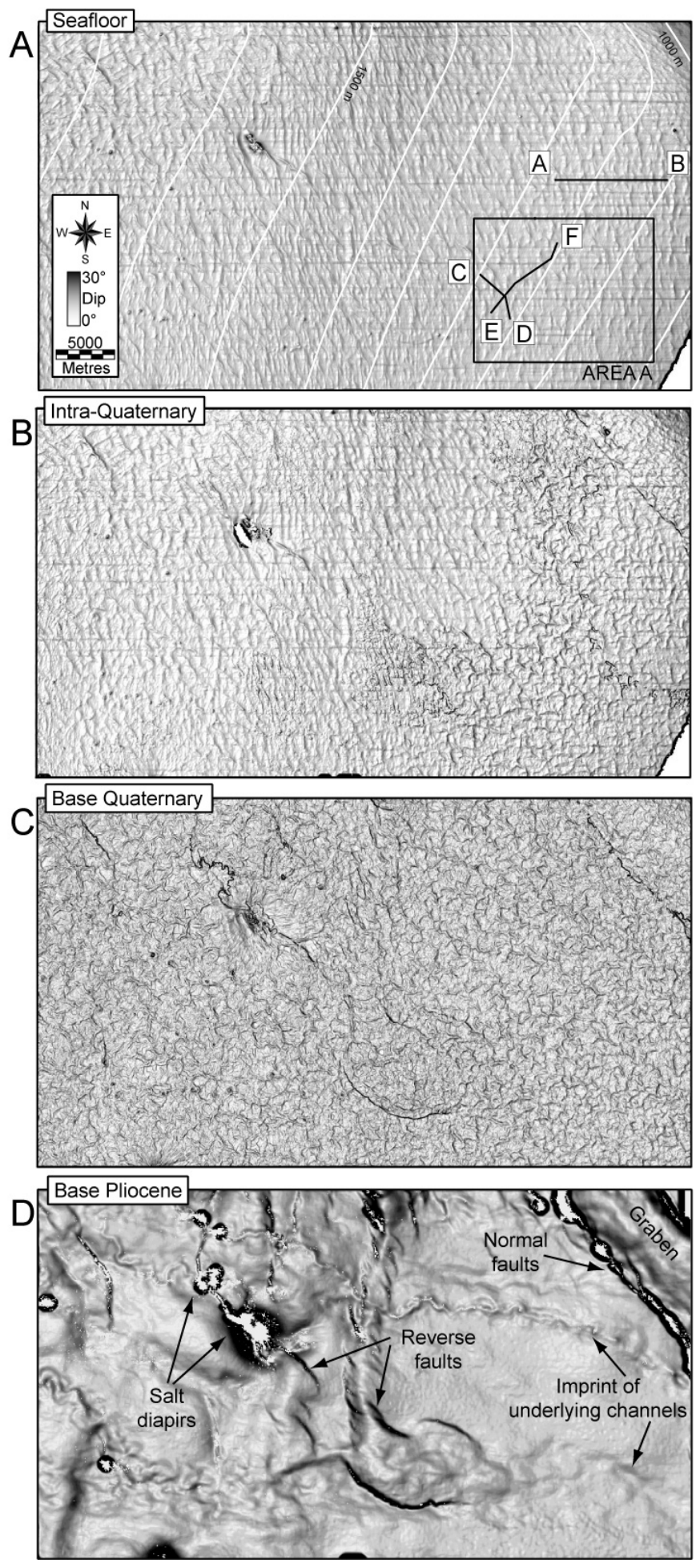


In order to constrain the fabric of the HFI, five horizons have been mapped within the $195 \mathrm{~km}^{2}$ Area A (see Fig. 4 for location): Seafloor, intra Quaternary, base Quaternary, intra Pliocene and base Pliocene (Fig. 5). As previously demonstrated, the furrows branch downward to the N-S edges of the polygonal network. Polygons range from 1 to $3 \mathrm{~km}$ in size and they share their edges with the adjacent polygons. The polygons fragment downward into smaller polygons. In particular, smaller polygons, $200-500 \mathrm{~m}$ wide, fit into larger polygons, 1-3 km wide, within the Pliocene interval. At the base of the Pliocene, only small polygons $(<200 \mathrm{~m})$ remain slightly visible. They locally fit into larger one $(200-500 \mathrm{~m}$ or $1-3 \mathrm{~km})$. At deeper burial depth, smaller polygons may exist but it is not possible to identify them, due to the vertical resolution of seismic data. We consider that the underlying horizons are not affected by the polygonal faulting. 


\section{A. Gay et al}

Figure 5: Detailed dip maps of five horizons (Seafloor, intra Quaternary, base Quaternary, intra Pliocene and base Pliocene) within Area A. The polygonal pattern of furrows appears on the intra Quaternary horizon. The polygons are vertically correlated with underlying polygonal faults, 1 to $3 \mathrm{~km}$ wide, on the base Quaternary horizon and on the intra Pliocene horizons. On the intra Pliocene horizon, smaller polygons, 100-200 m wide, fit into larger polygons (1 to $3 \mathrm{~km}$ ). On the base Pliocene, only very small polygons $(<200 \mathrm{~m})$ are visible and they fit into larger polygons $(200-500 \mathrm{~m}$ or $1-3 \mathrm{~km})$. An example is shown with a bold black polygon.

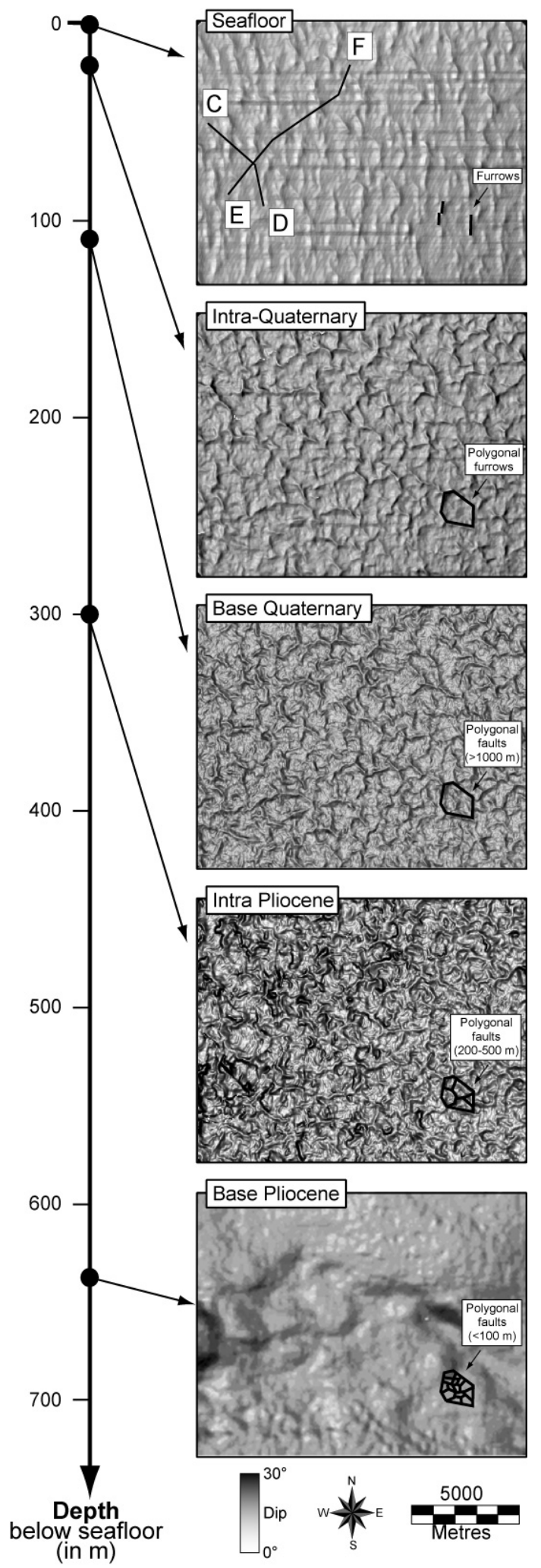




\section{A. Gay et al}

On seismic profiles, the seafloor furrows are seen as small depressions, a few metres deep (Fig. 6). The comparison between the furrows on the seafloor and the intra-Quaternary horizon demonstrates that a large number of furrows are common to both horizons. They are vertically superposed but their depth increases with burial. A remarkable feature of the HFI in the Lower Congo Basin is that the superposed N-S furrows are consistently located above "major" faults affecting the entire faulted interval. Deformation increases with depth: it starts on the seafloor with the formation of shallow N-S furrows, and evolves downwards to deeper and deeper furrows, until a fracture characterized by reflectors offsets can be seen from the base Quaternary at about $78 \mathrm{~m}$ below seafloor and below.

Figure 6: Detailed morphological structure of furrows on cross section. In the Quaternary section, the furrows are vertically superposed. This seismic profile shows that the depth of furrows increased with burial, suggesting an increase of deformation. At $78 \mathrm{~m}$ below seafloor, the furrows are correlated with a major fault affecting the entire HFI. This level corresponds to depth where faults are visible on seismic section.

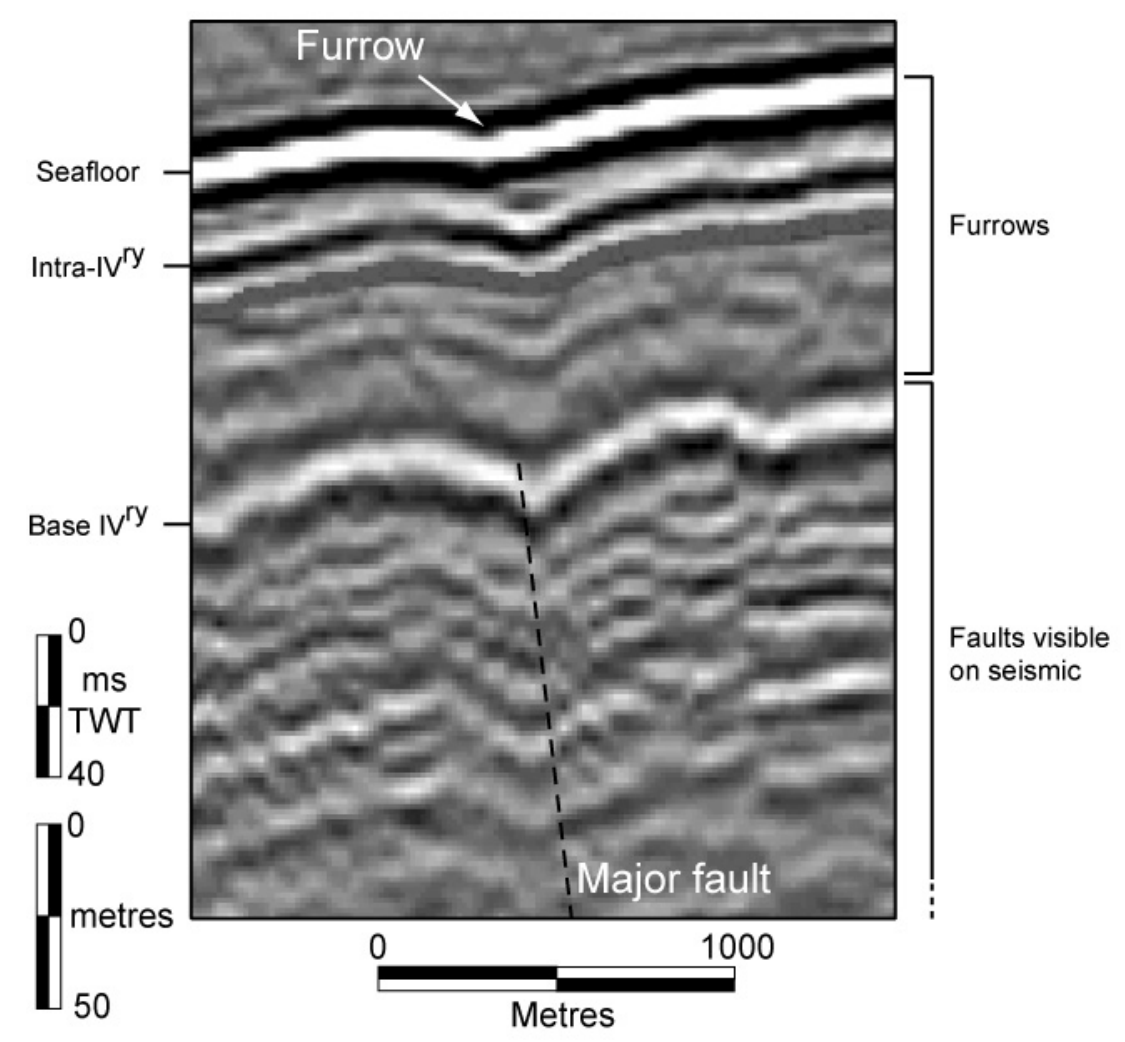

\section{EVOLUTION FROM FURROWS TO SMALL EXTENSIONAL FAULTS}

In order to clarify the organization of the upper part of the HFI, the length and the azimuth of each furrow have been measured on curvature maps on the seafloor and on the shallow intra Quaternary horizon within the Area A. 


\section{Statistical analyses of seafloor-furrows within Area A}

The systematic mapping of furrows displays a complex organisation in plan view (Fig 7). The axes of depressions are not exactly rectilinear; they result from the coalescence of several shorter furrows or segments. Although mapping of the furrows on the curvature map shows a main N-S orientation, other directions can be identified on the seafloor. For the statistical measurements, each segment was considered as an individual furrow. This allows 520 furrows to be identified in Area A with a density of 2.7 furrows $/ \mathrm{km}^{2}$. The graph of the frequency of furrows versus length and azimuth points out: 1) one dominant population of furrows, mainly oriented $\mathrm{N}-\mathrm{S}$ with an average length of $270 \mathrm{~m}$; 2) an accessory population of furrows with azimuths ranging from N100 to N140 and an average length of $270 \mathrm{~m}$.

Figure 7: Mapping of furrows within Area A on the seafloor. The furrows resulted from the coalescence of several shorter segments. The graph of the frequency of furrows versus length and azimuth allows the identification of two main populations: 1) a dominant population of furrows oriented N-S with an average length of $270 \mathrm{~m}$ and 2) an accessory population of furrows with azimuth ranging from N100 to N140 and an average length of $270 \mathrm{~m}$.
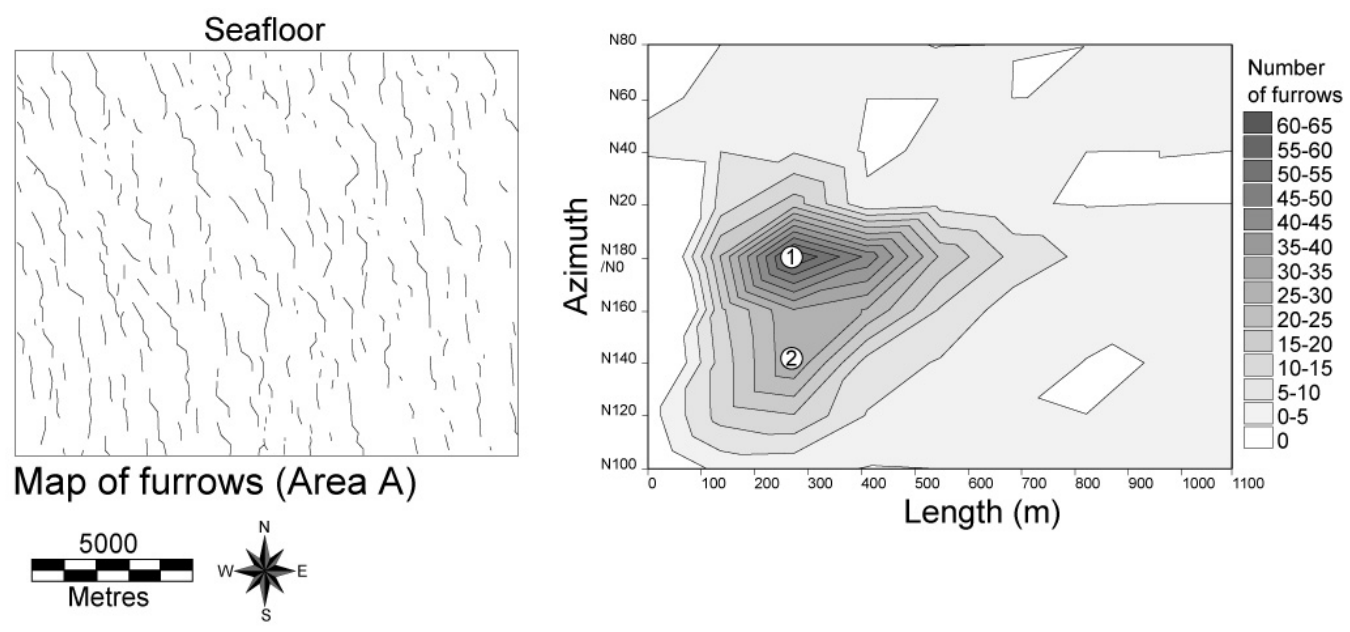

\section{Statistical analyses of intra-Quaternary-furrows within Area A}

The same method has been applied to the shallow buried intra-Quaternary horizon (Fig 8). A total amount of 1644 furrows have been counted, representing a density of 8.4 furrows $/ \mathrm{km}^{2}$. The graph of the frequency of furrows versus length and azimuth displays three distinct populations: 1) the same population as on the seafloor, with an azimuth of NO and an average length of $270 \mathrm{~m} ; 2$ ) another population previously identified on seafloor, with an azimuth of N120 and an average length of $270 \mathrm{~m}$; and 3) an accessory population with shorter furrows characterized by a new azimuth of $\mathrm{N} 40$ and an average length of $200 \mathrm{~m}$. The detailed mapping of furrows shows that they form a hexagonal pattern. The three identified directions (N0, N120 and N40) approach the directions necessary to form a hexagon, as shown on Figures 7 and 8. 


\section{A.Gay et al}

Figure 8: Mapping of furrows within Area A on the intra Quaternary horizon. The total number of furrows is greater than on the seafloor and they are organised to form a polygonal pattern. The furrows previously mapped on the seafloor have been identified on the shallow buried Horizon 1 . However, the graph of the frequency of length versus azimuth allows the identification of three well-defined populations of furrows: 1) a dominant population of furrows oriented N-S, $270 \mathrm{~m}$ long, 2) another dominant population of furrows oriented N120 with an average length of $270 \mathrm{~m}$ and 3) an accessory population of shorter furrows, $200 \mathrm{~m}$ long and oriented N40. The detailed mapping displays that the majority of furrows follows these directions to form an hexagonal network rather than a polygonal pattern in plan view.
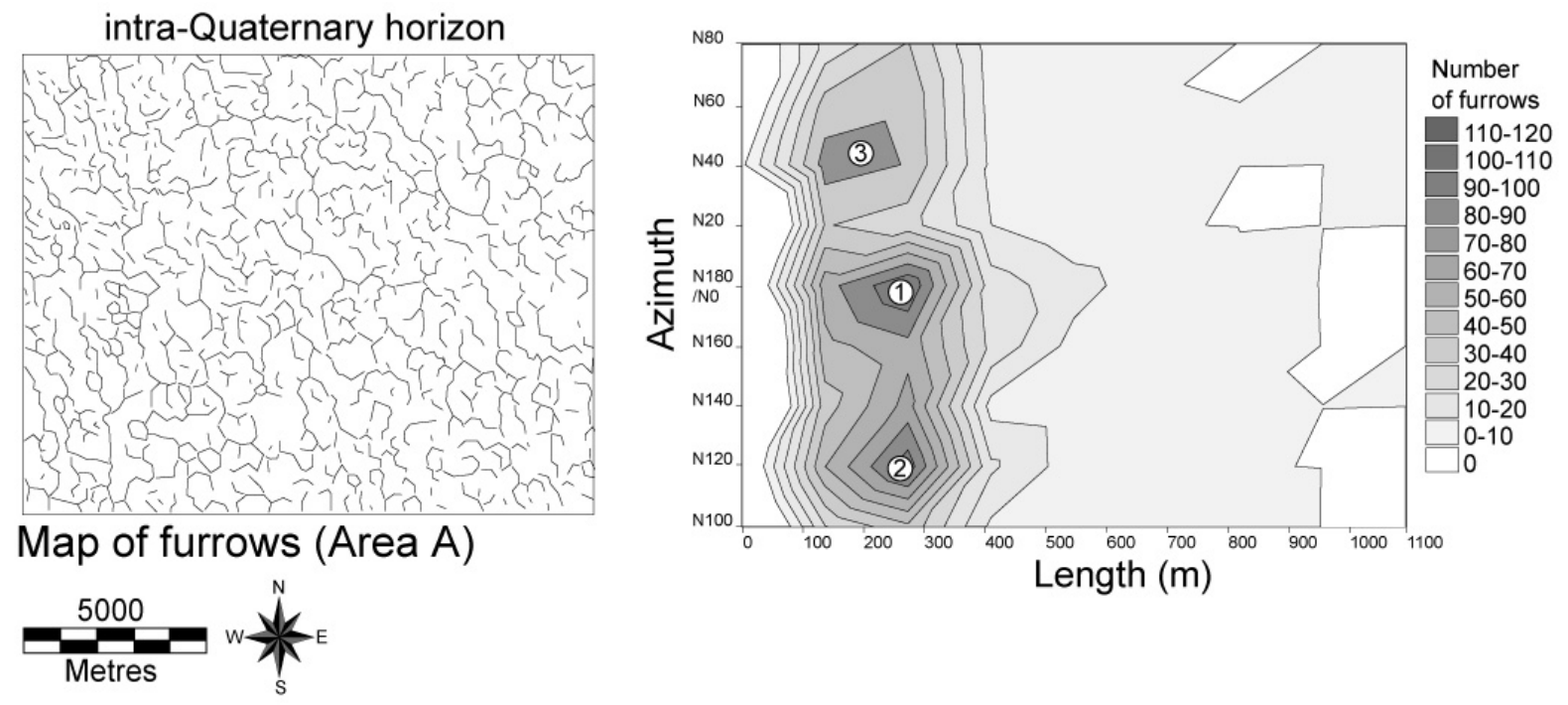

\section{REAL GEOMETRIES OF THE HEXAGONAL PATTERN: INTERNAL ORGANIZATION OF THE HFI}

In order to investigate geometrical relations between the furrows/HFI system and the slope, we have generated a random profile (Profile CD, Fig. 9) that is close to dip-parallel and oblique to perpendicular to the furrows on the seafloor. This profile indicates that furrows are located above the major faults, which affect the entire HFI. They are represented with a bold black line on Figure 9 and they are named "first order faults". These faults are consistently N-S oriented and they dip towards the East, i.e. away from the basin. As clearly visible on this seismic profile, the throw along the faults increases with depth, reaching its maximum at $300 \mathrm{~m}$ below seafloor (marked by a high amplitude reflection on the interpreted line drawing of Figure 9, corresponding to the intra Pliocene horizon). From this level down to the base of the HFI the throw along the first order faults decreases but the number of smaller order faults increases. The seismic profile CD discloses that the polygonal fault system is organized in stratigraphically defined layers, with the deformation apparently being decoupled between the layers. The other families of faults are concentrated in a layer characterized by a distinct acoustic character and are not correlated with overlying furrows (Fig. 9). Faults that affect two or more layers are named "second order faults", with an average spacing of 200-500 m. Faults that affect only one layer are very closely spaced $(<200 \mathrm{~m})$; they are named "third order faults". The particularity of this system is that the third order faults fit into the second order faults and in the same way the second order faults fit into larger first order 
hexagonal cells. Hence, the HFI represents an assemblage of hexagonal prisms, such as exhibited by "Russian dolls". Each of them represents a cell, which is isolated from the neighbouring hexagonal cells by faults. The seismic horizons within the HFI exhibit faults consistently dipping towards the East, suggesting a dominoesstyle rotation for each hexagonal cell.

Figure 9: Random seismic profile $C D$, parallel to the slope and perpendicular to the furrows. The superposed furrows are located above the top of faults that affect all the HFI (order 1 faults). The profile displays that the other families of faults are concentrated in layers characterized by a distinct acoustic character and are not correlated with overlying furrows. Faults that affect two or more layers are named order 2 faults and faults concentrated in one layer are named order 3 faults. In a general sense, the frequency of faults increases with depth, suggesting that the volumetrical contraction is better developed at deeper levels. The seismic horizons affected by the HFI exhibit faults consistently dipping towards the East and giving the impression of an anticlockwise domino-style rotation of each hexagonal cell.

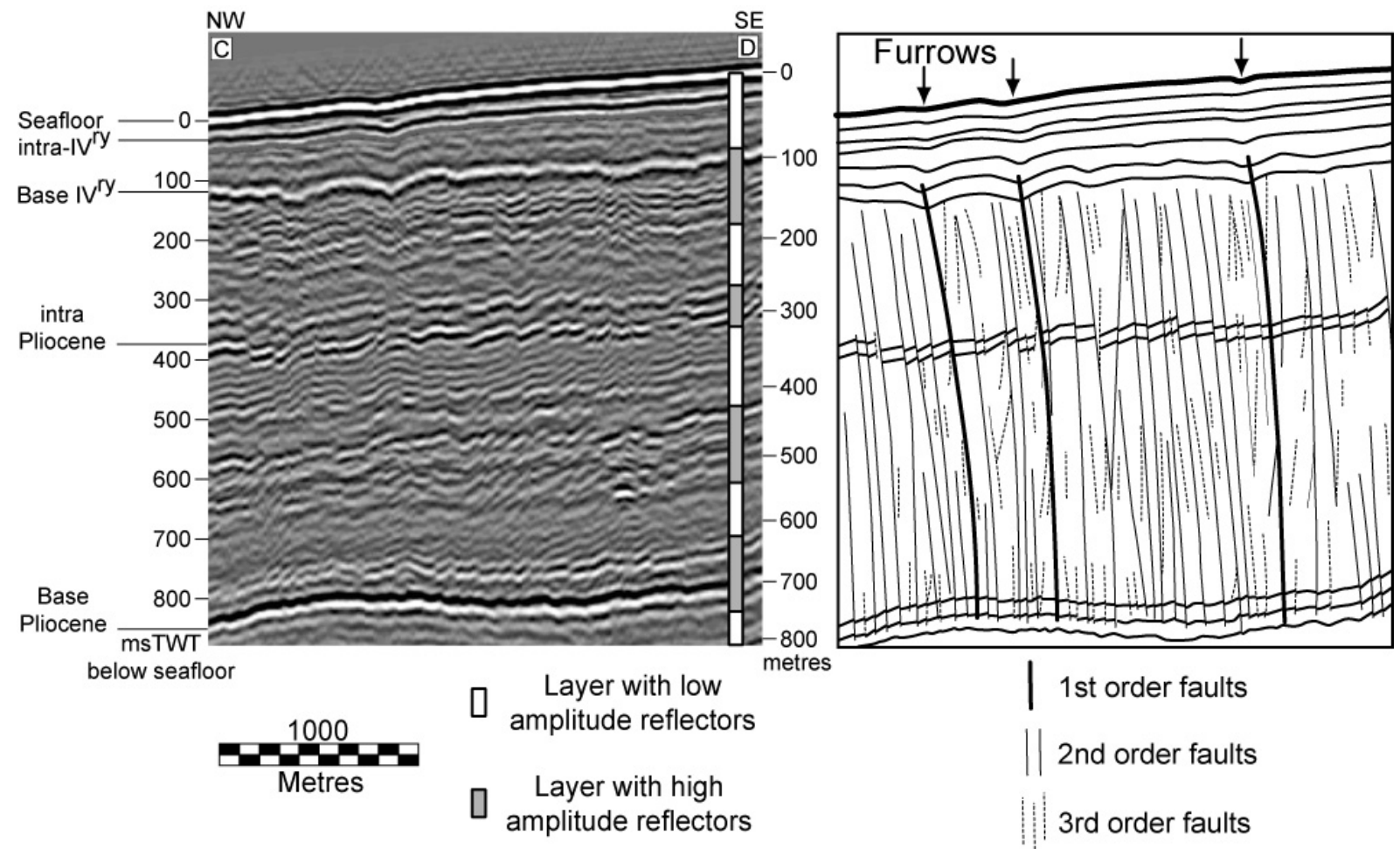

The seismic profile EF corresponds to a random line, simultaneously parallel to the strike of the slope and oblique to the N-S furrows (Fig. 10). Seismic markers, as on profile CD, shows a maximum offset across the first order faults. The second and third order faults are organized in layers corresponding to distinct acoustic characters. However, the main difference between profiles CD and EF is the dip of faults and their relationship with other order of faults. Successive first order faults display alternate dips (i.e. to the NE and to the SW) as shown in the Eromanga Basin (Watterson et al., 2000; Goulty, 2001). Second and third orders of faults are often conjugated. 


\section{A. Gay et al}

Figure 10: Random seismic profile EF, simultaneously perpendicular to the slope and to the edges of hexagons. As previously described on the Figure 7, three orders of faults, organised in layers, have been identified on this profile. Faults of a lower order are often conjugated to faults of the same order ( 3 to 3 or 2 to 2) or to faults of the upper order (3 to 2, 3 to 1 and 2 to 1 ). The high position of a cell of the bedding marker could be explained by a differential rotation of neighbouring hexagonal cells.
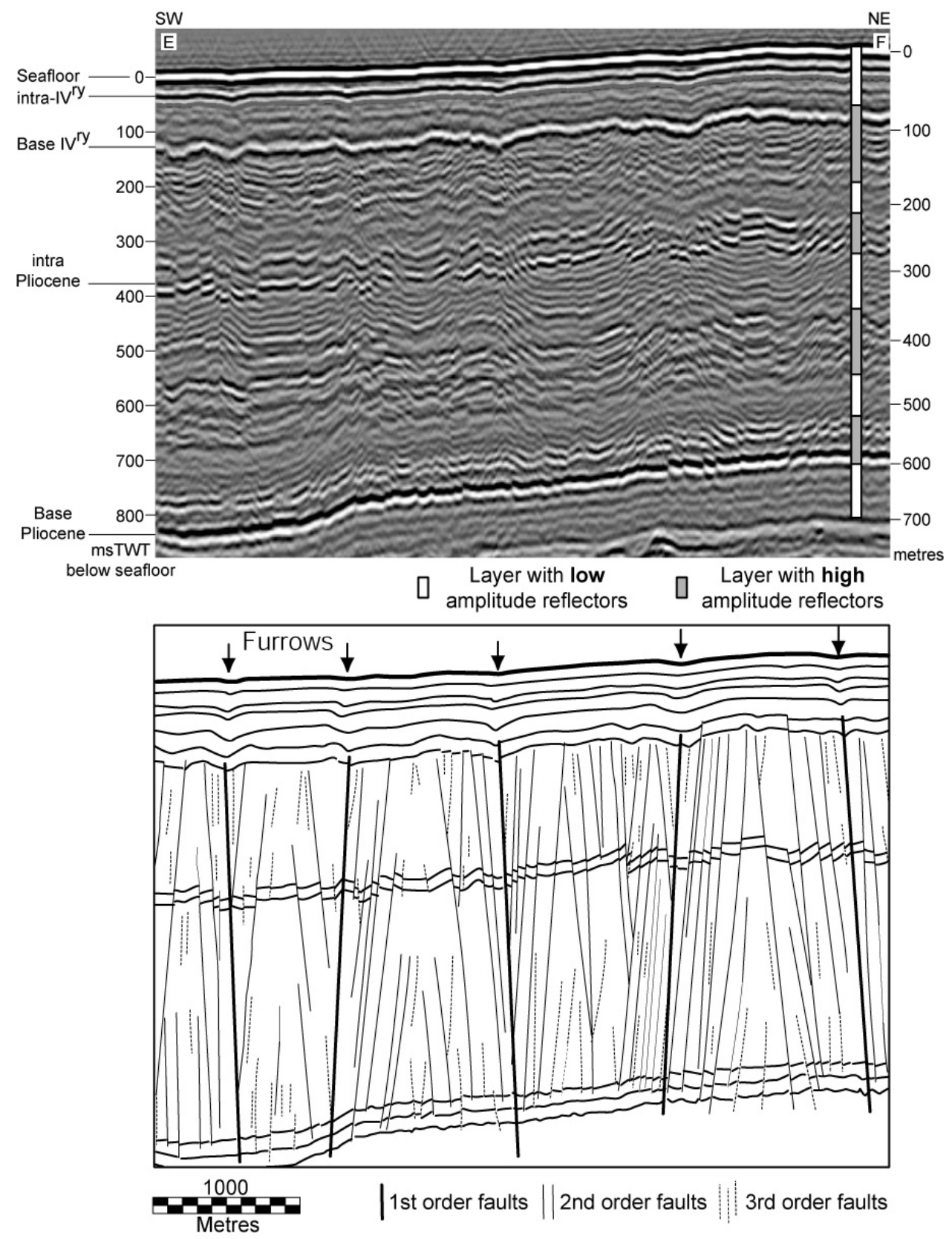

Although the three orders of faults are organized in layers, the interpretation of both profiles CD and EF displays that the concentration of faults increases with depth reaching its maximum nearby the base of the HFI. At this level ( $700 \mathrm{~m}$ below seafloor) the throw of faults is minimum but the deformation of hexagonal cells is maximum.

Both seismic profiles CD and EF have been depth converted using a TWTdepth function, based on well-seismic calibration. The line drawing of the profiles $C D$ and EF can therefore be shown without any vertical exaggeration (Fig. 11). A prevailing feature on both profiles is that all faults are not consistently rectilinear. On 


\section{A. Gay et al}

the seismic profile CD (i.e. parallel to the strike of the slope), all faults are convex to the East and they dip eastwards. Although the profiles are distorted by the depth conversion, furrows are always located exactly above the upper end of first order faults.

Figure 11: Seismic profiles EF and GH, represented with the real vertical scale in metres. On both profiles, the faults are not exactly rectilinear. The curved shape of faults suggests a progressive throwing during burial and sediment loading. The arrows represent the location of furrows on seafloor.
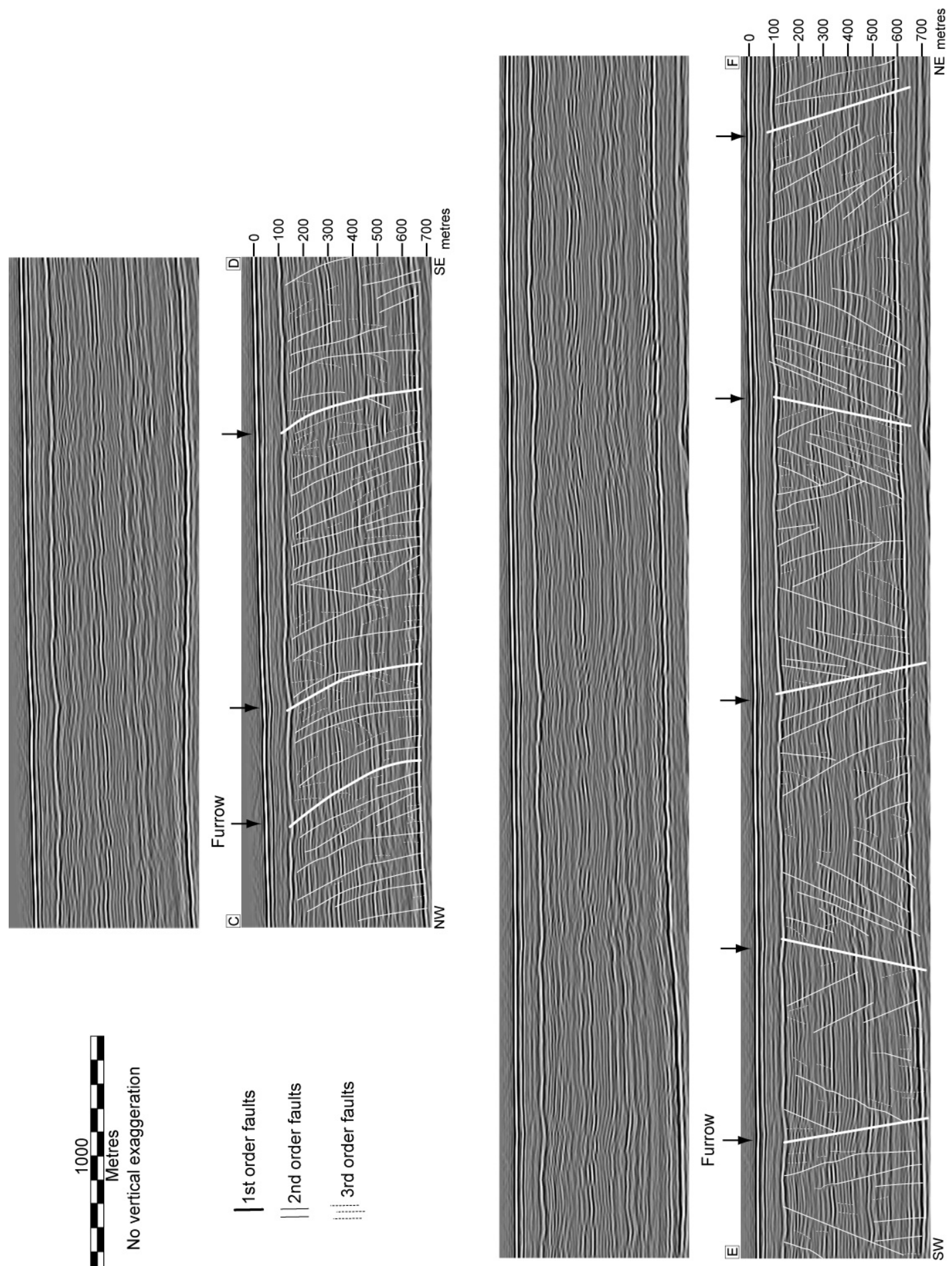


\section{DISCUSSION}

In most basin models, compaction and related phenomena are assumed to be due to mechanical effects in the first $0-2000 \mathrm{~m}$ in response to the progressive loading of sediments (Vasseur et al., 1995). As sediment porosity decreases with compaction, so does the permeability, due to a set of processes involving particle re-orientation and fluid expulsion leading to the decrease of void spaces between particles (Maltman, 1994; Vasseur et al., 1995). Overpressure development in sedimentary basins is thus directly related to lithology, sedimentation rate, thermal expansion of fluids, transformation of clay minerals and hydrocarbon generation or bacterial methanogenesis (Yu \& Lerche, 1996). Among these factors, grain size and sedimentation rates are of primary importance in controlling fluid pressure development in a basin.

\section{Mechanisms controlling fault development}

ODP Leg 175 results showed an overall seaward decrease of the sedimentation rate towards the basin (Wefer et al., 1998). The isopach map between seafloor and the intra-Quaternary horizon illustrates the progradational wedge formation (Fig. 12): the sediment thickness decreases from $46 \mathrm{~m}$ in the East to a few $\mathrm{m}$ in the West corresponding to the basinward decrease of the terrigenous input. On this figure, the thick zone (46 to $21 \mathrm{~m}$ ) exactly corresponds to the eastern zone of the intra Quaternary horizon intensively affected by the polygonal pattern of furrows (Fig. 4). The previously described western zone, which is only deformed by rectilinear furrows, corresponds to a thin cover $(<21 \mathrm{~m})$. It thus appears that there is a close relationship between the occurrence of the polygonal fault network and the sediment loading. 


\section{A.Gay et al}

Figure 12: Isopach map of the Seafloor-Horizon 2 interval, illustrating the formation of a progradational wedge during the Late Quaternary. The thickness decreases from $46 \mathrm{~m}$ in the East to a few metres in the West corresponding to the progressive disappearance of the terrigenous input basinward. The limit between blue and grey corresponds exactly to the western limit of the area characterized by a polygonal pattern identified on the intra Quaternary horizon. There is a close relationship between the occurrence of the polygonal network of furrows and the sediment loading.

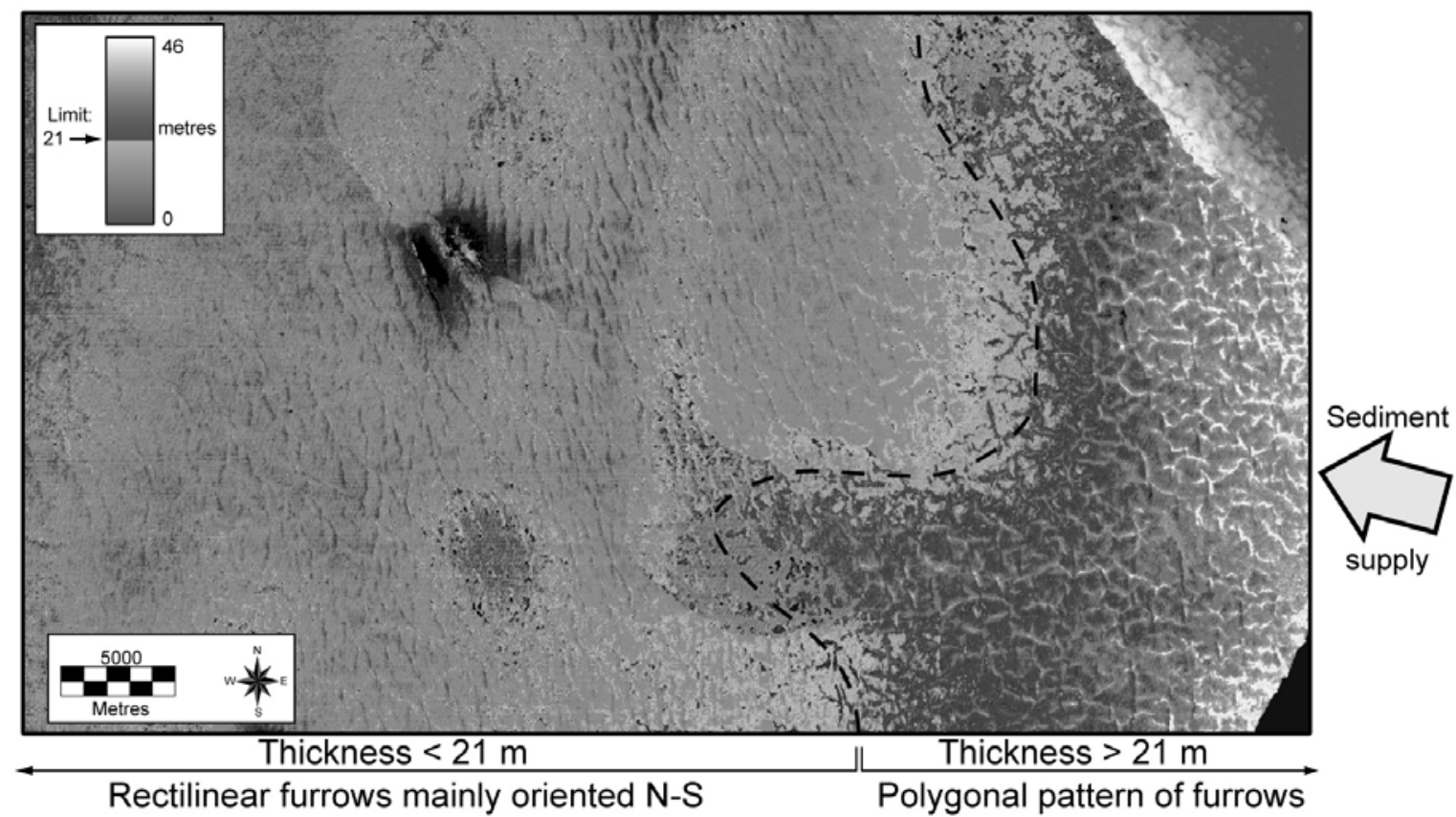

Cartwright \& Lonergan (1996) discussed two distinct strain paths as alternative explanations for the observed strain in the North Sea. Their first hypothesis considers a finite bed length extension and the development of conjugate shear planes with extensional offsets due to the loss of pore fluids. This process leads to a thinned sequence, which is partly compacted. In the second hypothesis, the authors consider that there is no change in the horizontal length and shear planes represent an apparent extension. For these reasons the authors argue that the complex polygonal fault system in the Palaeocene-Miocene mudstone-dominated sequences in the North Sea formed due to volumetric contraction during compactional dewatering (Cartwright \& Lonergan, 1996). This process is believed to occur in response to fluid expulsion during early compaction. The shallow origin of the faults can be evidenced by the recognition of growth sequences developed in their hangingwalls (Cartwright \& Lonergan, 1996). However, Early Tertiary mudrockdominated sequences affected by the polygonal system correspond to fossil systems, presently buried beneath overlying deposits.

Unlike the North Sea examples of faulted intervals (Cartwright \& Lonergan, 1996), our detailed study of the shallow polygonally faulted system in the Lower Congo Basin helps to improve the understanding of early processes of compaction. A curvature map of small-scale furrows on seafloor shows a bulge of the sediments immediately downslope of the furrow axis (Fig. 13), suggesting a contribution of gravitational processes. During early stages of compaction, sediments may contract volumetrically, opening cracks within shallow sediments and forming the furrows on seafloor. The orientation of furrows (i.e. the direction of opening) may be driven by 
the stress anisotropy of shallow sediments due to the gravitational sliding of the slope. In the study area, the occurrence of furrows on the seafloor may represent the first evidence of compaction mechanisms by slope-parallel volumetric contraction. This phenomenon leads to a bulk volume loss. The layer-parallel contraction of sediments during burial corresponds to a process of dewatering in which pore fluids are partly expelled near furrows. The low permeability of fine-grained argillaceous sediments would impede the pore fluid expulsion during burial. Cartwright (1994a) suggests that this process allows an increase in pore fluid pressure in the sealed layer, which could have triggered failure. Increased dewatering during burial may have caused more displacement along faults, which would continue to grow as long as the dewatering cell contracted volumetrically. This mechanism induces a component of tensile stress within the sediment mass resulting in the reduction of the horizontal effective stress. The Mohr circle can intersect the failure envelope in the shear domain leading to the propagation of non-vertical faults (Cartwright \& Lonergan, 1996; Dewhurst et al., 1999). The progressive reduction in bed length through contraction is balanced by an incremental increase in the amount of displacement distributed along the faults.

Figure 13: Detailed morphological structure of furrows in plan view. The curvature map of furrows shows that a bulge develops consistently basinward, suggesting a formation by gravitational sliding of shallow sediments. The orientation of furrows could be driven by the strain state of the shallow sedimentary column.
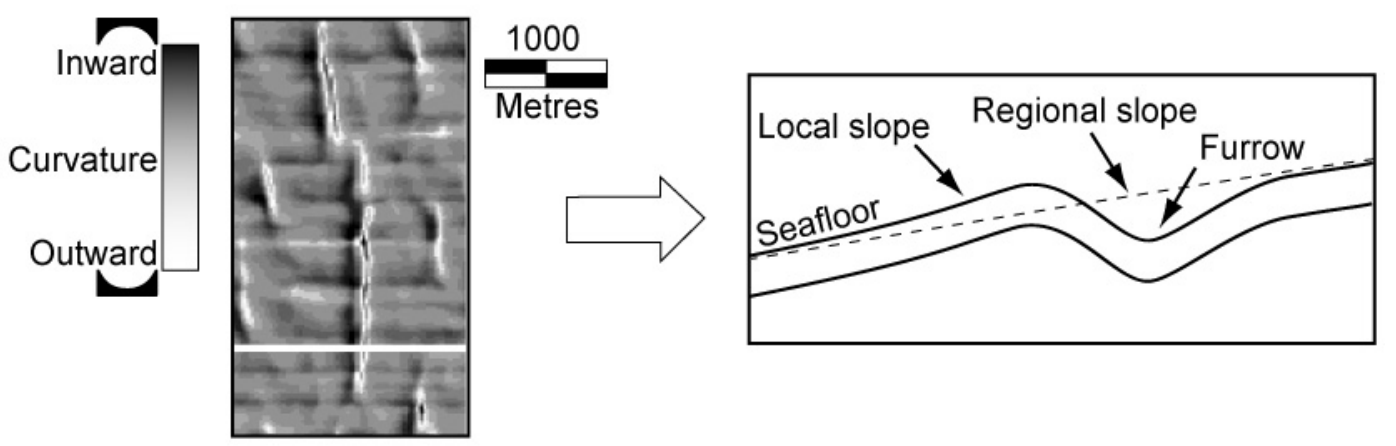

\section{A geometrical model for early stages of mud-dominated sediments compaction}

The development of polygonal fault systems seems highly dependent on a combination of the grain size and the mineralogy as demonstrated in the Early Tertiary mudrocks from the North Sea Basin (Dewhurst et al., 1999). In the North Sea, lithological analyses conducted on wells show that the amount of shrinkage in layers appears to increase as the grain size decreases and smectite content increases. In a more general sense, analyses of cuttings and XRD data point to grain size being a more important parameter than burial depth (Dewhurst et al., 1999).

The mud-dominated nature of slope sediments suggests that the deformation mechanism may be related to colloidal properties of such fine-grained sediments (Dewhurst et al., 1999). Current theories of one dimensional consolidation 
are based on the concept of gravitational loading with concomitant expulsion of pore fluid as a result of mechanical rearrangements of particles and porosity reduction. In the Lower Congo Basin, the horizontal volumetrical contraction of fine-grained sediments starts at the sediment-water interface in only one direction and it is driven by gravitational processes on the slope, as suggested by Dewhurst et al. (1999).

We propose for the Lower Congo Basin a geometrical model, which takes into account that the compaction rate is not laterally homogeneous within the first 700 $\pm 50 \mathrm{~m}$ below seafloor (Fig. 14). From the seafloor down to $21 \mathrm{~m}, \mathrm{~N}$-S furrows open perpendicular to the slope (i.e. E-W), following the direction of cracks opening due to the horizontal sliding of the sedimentary cover. From $21 \mathrm{~m}$ down to the base Quaternary, the deformation progressively increases with depth, leading to the formation of other families of furrows oriented N40 and N120. The three orientations of first order faults define hexagonal cells and the volumetrical contraction starts to be radial. All furrows are vertically correlated with first order faults also making up hexagonal pattern in plan view. From $78 \mathrm{~m}$, the fault offset is visible on seismic sections and increases with depth. In the Lower Congo Basin, the maximum offset of first order fault is reached at $300 \mathrm{~m}$. At deeper burial depths, compaction mechanisms need to develop other families of faults (second and third orders faults) for expelling pore fluids in the centre of first order hexagonal prisms. The fault frequency increases with depth, reaching its maximum at the base of the HFI (i.e. $700 \pm 50 \mathrm{~m}$ ). The fault density is such that the bedding is flattened. This corresponds to a large amount of fluid expelled and to the locking of this system. Compaction through this process may be finished. At deeper burial, other compaction processes of argillaceous sediments, such as pure chemical or mechanical compaction, are involved. 
Figure 14: Schematic block diagram showing the imbricated pattern of hexagonal cells of dewatering. The volumetrical contraction starts at the sediment-water interface, creating rectilinear furrows. The mono-directional contraction is parallel to the slope, suggesting that shallow gravitational processes control the orientation of furrows. At $21 \mathrm{~m}$ below seafloor, radial shrinkage leads to the development of hexagonal pattern of furrows, defining individual dewatering cells. At the base Quaternary, hexagonal first order faults, 1 to $3 \mathrm{~km}$ wide, are initiated. Continued shrinkage provides a mechanism to drive slip along fault planes that reaches its maximum at $300 \mathrm{~m}$ below seafloor. Further pore fluid expulsion requires the formation of more closely spaced polygonal faults (order 2 and 3 faults), fitting into hexagonal order 1 cells. At $700 \mathrm{~m}$ below seafloor, the concentration of faults reaches its maximum and the compaction by shrinkage is finished.

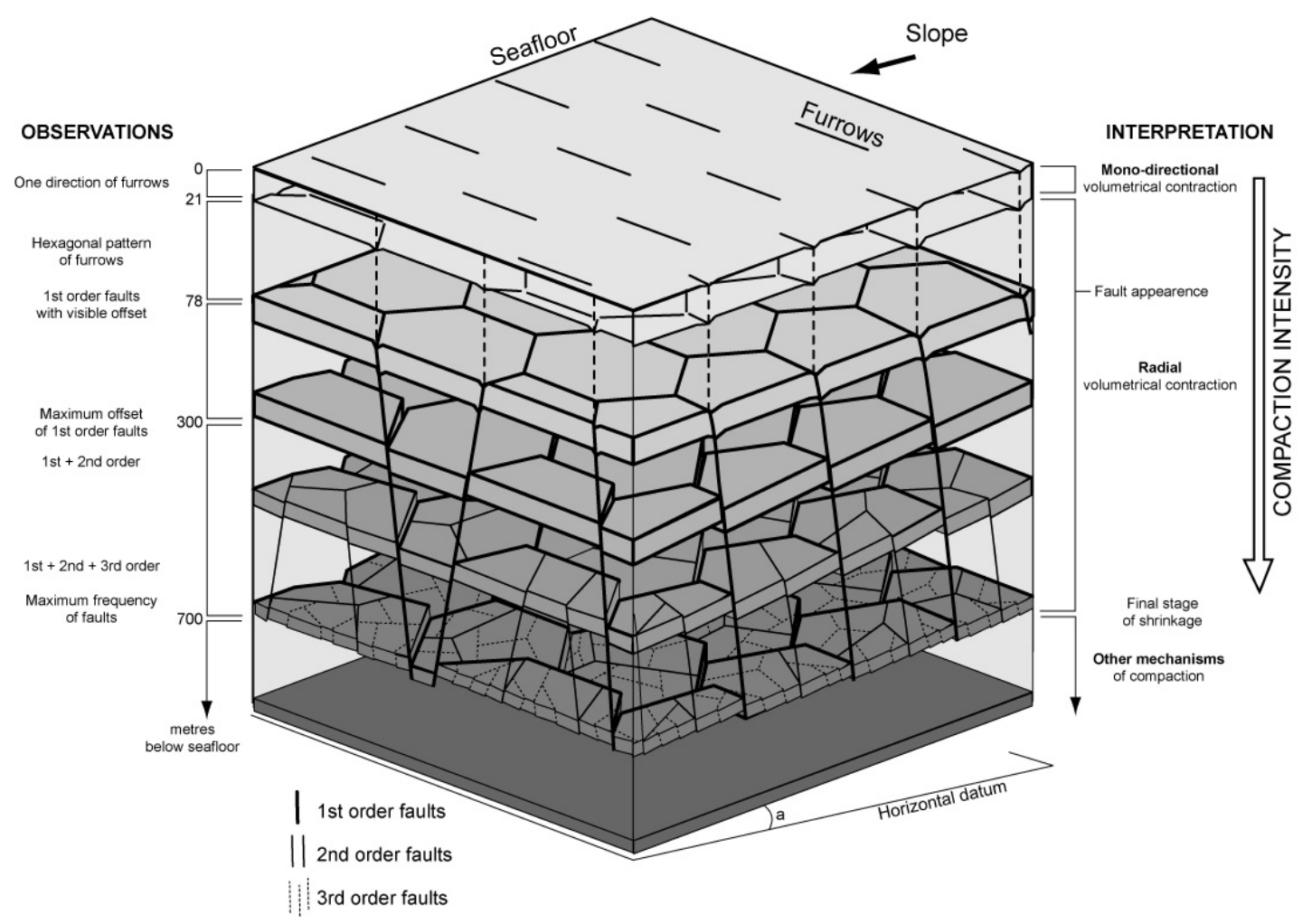

The main factor controlling the development of polygonal fault systems is the grainsize (Dewhurst et al., 1999). However, the orientation of furrows and underlying faults as well as their bending in the slope direction suggests the interaction of gravity-driven shearing of the compacting interval. The appearance of hexagonal fault system reaching the seafloor could thus be indicative of the present day strain state within the sedimentary column (Tuckwell et al., 2003).

\section{Implications for fluid migration from deeper levels}

If the faults are not sealed, the HFI represents an interval with a high drainage potential for pore fluids. In this context, fluids migrating from deeper levels are preferentially driven through this interval along the pre-existing first order faults, which crosscut all of the HFI. Fluid venting related of deeper origin is expressed on seafloor by erosional features named pockmarks (Heggland, 1998). The fault attribute allows the mapping of vertical discontinuities, such as faults of the HFI and 


\section{A. Gay et al}

fluid chimneys. In the study area, these chimneys are consistently located on the triple-junction of three hexagonal first order faults. Only faults that are N-S oriented are correlated with overlying superposed furrows reaching the seafloor. Consequently, pockmarks consistently appear at the extremity of furrows on seafloor (Fig 15). These observations are highly relevant to predictive models describing the occurrenc of pocekmarks on slopes characterized by fine-grained sediments.

Figure 15: Schematic diagram representing the relationship between furrows, pockmarks and hexagonal cells of dewatering. Fluids from deeper levels migrate through conduits that consistently develop at the intersection of three adjacent order 1 hexagons, evidenced by dip or fault attributes. This triple-point is characterized by a high drainage potential and seafloor pockmarks are mainly located at the extremity of N-S furrows.
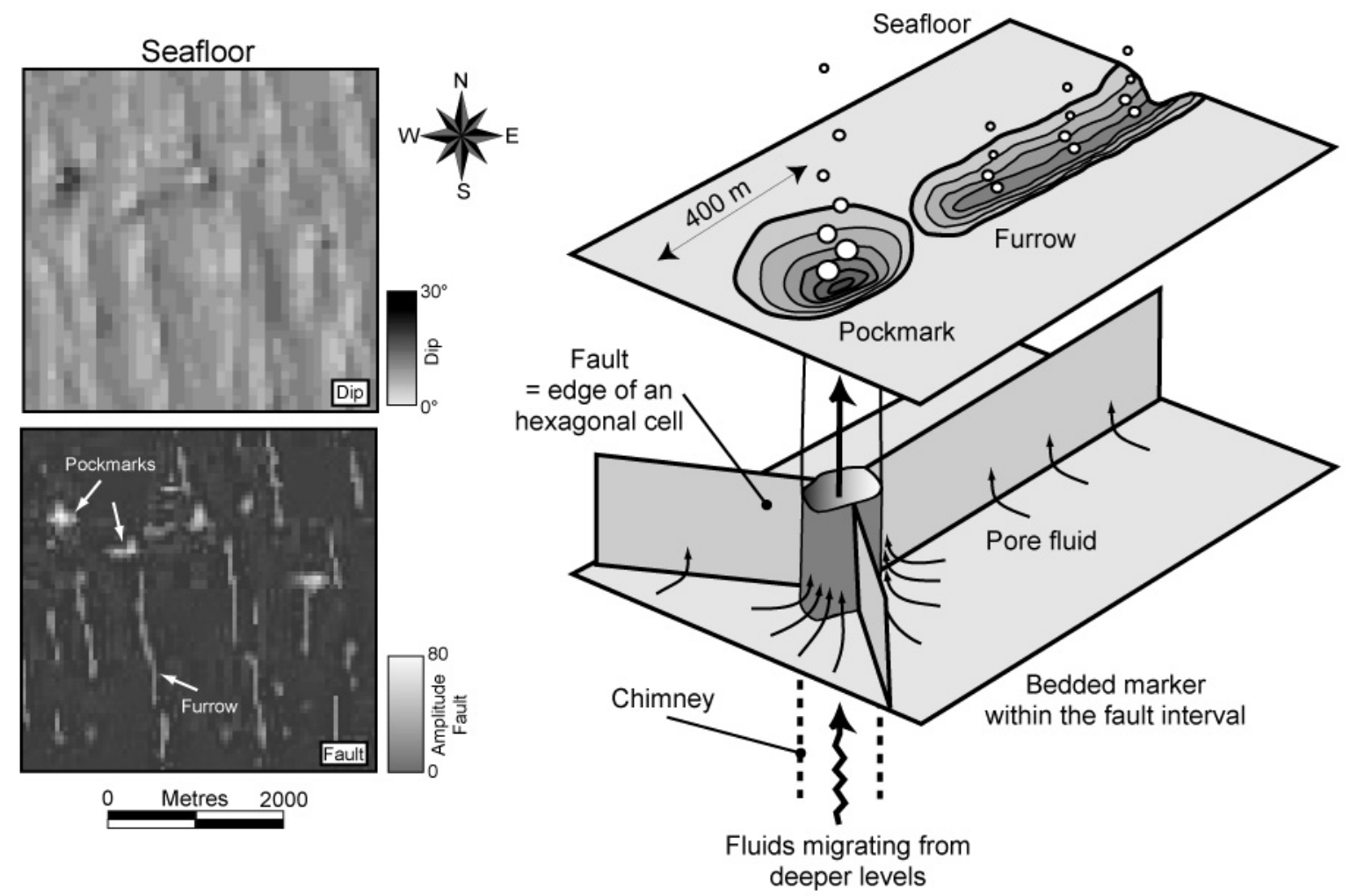

\section{CONCLUSION}

3D-seismic data provide new insights on the margin history and improve the understanding of post-depositional processes that affect the sedimentary column in the Lower Congo Basin. Contrary to previous studies using time-slices, the spacing of 3D-seismic grids allows the mapping of reflectors. This method preserves internal geometrical relations and provides high quality images of the seafloor and buried horizons. Several cross sections in the Lower Congo Basin display a closely spaced normal fault system affecting the upper $700 \mathrm{~m}( \pm 50 \mathrm{~m})$ of the sedimentary column, named a Highly Faulted Interval (HFI). These faults make up hexagonal network in 
plan view, which is characteristic of volumetric contraction of sediments in response to pore fluid escape. The process of compaction and dewatering is mainly due to the overburden load over fine-grained sediments. Although several faulted systems have been described worldwide (Cartwright \& Dewhurst, 1998), the example in the Lower Congo Basin is the only description of an active process reaching the present day seafloor.

In the light of this study, we propose a complementary model that integrates with previous hypotheses (Cartwright \& Lonergan, 1996; Lonergan et al., 1998; Dewhurst et al., 1999):

1) The volumetric contraction starts at the sediment-water interface, creating rectilinear furrows in the first $0-21 \mathrm{~m}$. The contraction is horizontal, parallel to the slope, suggesting that shallow gravitational processes control the orientation of furrows.

2) As proposed by Dewhurst et al (1999), a radial shrinkage occurs at shallow burial depth (from $21 \mathrm{~m}$ ). The layer-parallel contraction of the sediment leads to the formation of hexagonal pattern of furrows, outlining dewatering cells.

3) During burial, as the permeability decreases, the strength of the sediment increases, reaching a threshold at about $78 \mathrm{~m}$, where faulting can be expressed and hexagonal first order faults are visible on seismic sections below this depth.

4) Continued shrinkage provides a mechanism to drive slip along fault planes that reaches its maximum at $300 \mathrm{~m}$. Further pore fluid expulsion requires the formation of more closely spaced hexagonal faults (second and third order faults) and the hexagonal first order cells contain smaller hexagonal faults. Finally, the HFI is composed of small prisms fitting into larger prisms.

5) At an average depth of $700 \mathrm{~m}( \pm 50 \mathrm{~m})$, as the fault frequency reaches its maximum, the compaction by lateral shrinkage is finished.

During early compaction of mud-dominated sediments, numerous hexagonal faults have been initiated. The triple-junction of three neighboring hexagonal cells represents a preferential pathway for fluid migration from deeper levels, in particular thermogenic gas or oil, leading to the formation of pockmarks on the seafloor. The detailed study of highly faulted intervals should improve our knowledge of early compaction processes and help to better understand the seafloor distribution of fluid seepage features, such as furrows and pockmarks.

\section{ACKNOWLEDGEMENTS}

We gratefully acknowledge IFREMER and TOTAL for their financial support, seismic data supplies and for providing the seismic velocities polynomial law used to convert seismic profiles into depth profiles. Initial discussions with N. Sultan were invaluable in bridging the gap between mechanical constrains and geometrical model. M. Seranne provided insights into 3D model and tectonic point of view. M. Huuse and R. Davies are acknowledged for their critical reviews and their suggestions. We warmly thank J.A. Cartwright for his careful advice of faulted systems related to early stages of compaction.

\section{REFERENCES}


Brice, S. E., Cochran, M. D., PARdo, G. \& Edwards, A. D. (1982) Tectonics and Sedimentation of the South Atlantic Rift Sequence: Cabinda, Angola. In: Studies in Continental Margin Geology (Ed. by W. a. Drake), AAPG Memoir, 34, 5-18.

BRown, A.R. (1996) Interpretation of three-dimensional seismic data. AAPG Memoir, 42, $424 \mathrm{p}$.

Burollet, P. F. (1975) Tectonique en radeaux en Angola. Bull. Soc. Géol. de France, XXII, 503-504.

CARTWRIGHT, J. A. (1994a) Episodic basin-wide fluid expulsion from geopressured shale sequences in the North Sea basin. Geology, 22, 447-450.

CARTWRIGHT, J. A. (1994b) Episodic basin-wide hydrofracturing of overpressured Early Cenozoic mudrock sequences in the North Sea Basin. Mar. Petr. Geol., 11, (5), 587-607.

CARTWRIGHT, J. \& LONERGAN, L. (1996) Volumetric contraction during the compaction of mudrocks: a mechanism for the development of regional-scale polygonal fault systems. Basin Res., 8, 183-193.

CARTWRIGHT, J. A. \& LONERGAN, L. (1997) Seismic expression of layer-bound fault systems of the Eromanga and North Sea Basins. Expl. Geophys., 28, 323-331.

CARTWRIGHT, J. A. \& DEWHURST, D. N. (1998) Layer-bound compaction faults in finegrained sediments. Geol. Soc. Am. Bull., 110, (10), 1242-1257.

Clausen, O. R. \& J. A. Korstgard (1993). Small scale faulting as an indicator of deformation mechanism in the Tertiary sediments of the northern Danish Central Trough. J. Struct. Geol., 15, 1343-1358.

Clausen, J. A., R. H. Gabrielsen, et Al. (1999). Development of intraformational (Oligocene-Miocene) faults in the northern North Sea: influence of remote stresses and doming of Fennoscandia. J. Struct. Geol., 21, (10), 1457-1475.

COOPER, C. K. (1999) Ocean currents offshore Northern Angola. OTC, paper 10749, DeWhurst, D. N., CARTWRight, J. \& Lonergan, L. (1999) The development of polygonal fault systems by syneresis of colloidal sediments. Mar. Petr. Geol., 16, 793-810.

Droz, L., Rigaut, F., Cochonat, P. \& Tofani, R. (1996) Morphology and recent evolution of the Zaire turbidite system (Gulf of Guinea). Geol. Soc. Am. Bull., 108, (3), 253-269.

Duval, B., Cramez, C. \& Jackson, M. P. A. (1992) Raft tectonics in the Kwanza basin, Angola. Mar. Petr. Geol., 9, 389-404.

Giraudeau, J., Christensen, B. A., Hermelin, O., Lange, C. B., Motoyama, I. \& PARTY, A. S. S. (1998) Biostratigraphic age models and sedimentation rates along the southwest African Margin. In: Proc. ODP, Initial reports (Ed. by G. Wefer, W. H. Berger and C. Richter), 175, p. 543-546.

GoULTY, N. R. (2001). Mechanics of layer-bound polygonal faulting in fine-grained sediments. J. Geol. Soc. of London, 159, 239-246.

HEGGLAND, R. (1998) Gas seepage as an indicator of deeper prospective reservoirs. A study based on exploration 3D seismic data. Mar. Petr. Geol., 15, 1-9.

HenRIET, J.-P., BAtist, M. D. \& VerschuREN, M. (1991) Early fracturing of Palaeogene clays, southernmost North Sea: Relevance to mechanisms of primary hydrocarbon migration. In: Generation, Accumulation and Production of Europe's Hydrocarbons (Ed. by A. M. Spencer), Eur. Ass. Petr. Geol., Sp. Pub., 1, 217-227.

Jansen, J. H., Weering, T. C. E. V., Gieles, R. \& IPRESEN, J. V. (1984) Middle and Late Quaternary oceanography and climatology of the ZAIRE-Congo fan and the adjacent eastern Angola Basin. Neth. J. Sea Res., 17, 201-249. 
KIDD, G. D. (1999) Fundamentals of 3D seismic volume visualization. OTC, paper 11054,

KLITGORD, K. D. \& GROW, J. A. (1980) Jurassic seismic stratigraphy and basement structure of the western Atlantic magnetic quiet zone. AAPG Bulletin, 64, 1658-1680. LACHENBRUCH, A. H. (1962) Mechanics of thermal contraction cracks and ice-wedge polygons. Geol. Soc. Am., Sp. Paper, 70.

LAVIER, L., M. STECKLER, et al. (2000). An improved method for reconstructing the stratigraphy and bathymetry of continental margins: Application to the Cenozoic tectonic and sedimentary history of the Congo margin. AAPG Bulletin, 84, (7), 923939.

LAVIER, L., M. S. SteCKLeR, et al. (2001). Climatic and tectonic control on the Cenozoic evolution of the West African margin. Mar. Geol., 178, 63-80

LIRO, L. M. \& COEN, R. (1995) Salt deformation history and postsalt structural trends, offshore southern Gabon, West Africa. In: Salt Tectonics: a Global Perspective (Ed. by M. P. A. Jackson, D. G. Roberts and S. Snelson), AAPG Memoir, 65, 323-331.

LONERGAN, L., CARTWRIGHT, J. \& JOLLY, R. (1998) The geometry of polygonal fault systems in Tertiary mudrocks of the North Sea. J. Struct. Geol., 20, (5), 529-548.

LUNDIN, E. R. (1992) Thin-skinned extensional tectonics on a salt detachment, northern Kwanza Basin, Angola. Mar. Petr. Geol., 9, 405-411.

Maltman, A. (1994) The Geological Deformation of Sediments, Chapman \& Hall, London.

MARTON, L. G., TARI, G. C. \& Lehmann, C. T. (2000) Evolution of the Angola passive Margin, West Africa, with Emphasis on Post-Salt Structural Styles. In: Atlantic Rifts and Continental Margins (Ed. by W. Moriak and M. Talwani), Am. Geophys. Un., 129149.

Oldham, A. C. \& GibBins, N. M. (1995) Lake Hope 3D: A case study. Expl. Geophys., 26, 383-394.

PoAg, C. W., Watts, A. B. \& Others (1987) Initial Reports of the Deep Sea Drilling Project, 95. U.S. Government Printing Office, Washington D.C.

PufAHL, P. K., MASLIN, M. A., ANDERSON, L. \& AL, E. (1998) Lithostratigraphic summary for LEG 175: Angola-Benguela upwelling system. In: Proc. ODP, Initial reports (Ed. by G. Wefer, W. H. Berger and C. Richter), 175, 533-542.

Rouby, D., Raillard, S., Guillocheau, F., Bouroullec, R. \& Nalpas, T. (2002) Kinematics of a growth fault/raft system on the West African margin using 3-D restoration. J. Struct. Geol., 24, 783-796.

SAVOYE, B., COCHONAT, P. \& shipboard scientific party (2000) Structure et évolution récente de l'éventail turbiditique du Zaire: premier résultats scientifiques des missions d'exploration Zaiango 1 et 2 (Marge Congo-Angola). C-R. Ac. Sci. de la Terre et des Planètes, 331, 211-220.

SÉRANNE, M. (1999) Early Oligocene stratigraphic turnover on the West Africa continental margin: a signature of the Tertiary greenhouse-to-icehouse transition ? Terra Nova, 11, 135-140.

SÉrAnNe, M., SÉguret, M. \& FAuchier, M. (1992) Seismic super-units and post-rift evolution of the continental passive margin of southern Gabon. Bull. Soc. Géol. de France, 163, (2), 135-146.

TUCKWELL, G. W., L. LONERGAN AND R. JOLLY (2003). The control of stress history and flaw distribution on the evolution of polygonal fracture networks. J. Struct. Geol., 25, 1241-1250. 
UCHUPI, E. (1992) Angola Basin: Geohistory and Construction of the Continental Rise. In: Geologic Evolution of Atlantic Continental Rifts (Ed. by P. a. D. Graciansky), Nostrand Reinhold, 77-99.

Uenzelmann-Neben, G. (1998) Neogene sedimentation history of the Congo Fan. Mar. Petr. Geol., 15, 635-650.

Vasseur, G., Dueran-Maigre, I., Grunberger, D., Rousset, G., Tessier, D. \& VELDE, B. (1995) Evolution of structural and physical parameters of clays during experimental compaction. Mar. Petr. Geol., 12, (8), 941-954.

Watterson, J., J. Walsh, A. Nicol, P. A. R. Nell AND P. G. Bretan (2000). Geometry and origin of a polygonal fault system. Journal of Geological Society 157, 151-162.

Wefer, G., Berger, W. H. \& RICHTER, C. (1998) Proc. ODP, Initial Reports, 175.

Wefer, G., Berger, W. H., RICHTER, C. \& PARTY, A. S. S. (1998) Facies patterns and authigenic minerals of upwelling deposits off Southwest Africa. In: Proc. ODP, Initial reports (Ed. by WeFER, G., BERGER, W. H. \& RICHTER, C.), 175, 487-504.

WEINBERGER, R. (1999) Initiation and growth of cracks during desiccation of stratified muddy sediments. J. Struct. Geol., 21, 379-386.

Yu, Z. \& LERCHE, I. (1996) Modelling abnormal pressure development in sandstone/shale basins. Mar. Petr. Geol., 13, (2), 179-193. 